soluble and particulate fraction of the liver, whereas the other two patients were deficient in such an activity. Partially purified$\beta$-glucosidase from acute infantile Gaucher's liver exhibited no activity measured with glucocerebroside as a substrate whereas those from juvenile Gaucher's liver showed considerable activity. These results suggest the possibility that a new type of genetic heterogeneity may be involved in neuropathic Gauchers disease.

\section{REFERENCES AND NOTES}

1. Beutler, E., and Kuhl, W.: The diagnosis of the adult type of Gaucher's disease and its carrier state by demonstration of deficiency of $\beta$-glucosidase activity in peripheral blood leukocytes. J. Lab. Clin. Med., 76: 747 (1970).

2. Beutler, E., Kuhl, W., Trinidad, F., Teplitz, R., and Nadler, H.: $\beta$-Glucosidase activity in fibroblasts from homozygotes and heterozygotes for Gaucher's disease. Amer. J. Hum. Genet., 23: 62 (1971).

3. Brady, R. O., Kanfer, J. N., and Shapiro, D.: Aetabolism of glucocerebror sides II. Evidence of an enzymatic deficiency in Gaucher's disease. Biochem. Biophys. Res. Commun., 18: 221 (1965).

4. Brady, R. O., Kanfer, J. N., Bradley, R. M., and Shapiro, D.: Demonstration of a deficiency of glucocerebroside-cleaving enzyme in Gaucher's disease. J. Clin. Invest., 45: 1112 (1966).

5. Folch, J., Lees, M., and Sloane Stanley, G. H.: A simple method for the isolation and purification of total lipids from animal tissues. J. Biol. Chem.. 226: 497 (1957).

6. Handa, S., and Yamakawa, T.: Biochemical study in cat and human gangliosidosis. J. Neurochem., 18: 1275 (1971).

7. Hultberg, B., and Öckerman, P. A.: $\beta$-Glucosidase activities in human tissues findings in Gaucher's discase. Clin. Chem. Acta, 28: 169 (1970).

8. Hultberg, B., Sjoblad, S., and Ockerman, P. A.: 4-Methylumbelliferyl- $\beta$ glucosidase in cultured human fibroblasts from controls and patients with Gaucher's disease. Clin. Chem. Acta, 49: 93 (1973).

9. Kampine, J. P., Brady, R. O., Kanfer, J. N., Feld, M., and Shapiro, D.: Diagnosis of Gaucher's discase and Niemann-Pick discase with small samples of venous blood. Science, 155: $86(1967)$.

10. Kanfer J. N., Raghavan, S. S., Numford R. A., Labow R. S., Williamson I). G., and Layne D. S.: Deficiency of steroid $\beta$-glucosidase in Gaucher disease. Biochem. Biophys. Res. Commun., 67: 683 (1975).

11. Klibansky, C., Hoffmann, J., Pinkhas, J., Algom, D., Dintzman, M., BenBassat, M., and de Vries, A.: Leukocyte glucocerebrosidase deficiency diagnostic in adult Gaucher's disease with negative bone marrow biopsy.
Some properties of the enzyme in leukocytes and spleen. Lur. J. Ctin. Invest., 4: $101(1974)$.

12. Kwitcrovich, P. O., Sloan, H. R., and Fredrickson, D. S.: Glycolipids and other lipid constituents of normal human liver. J. Lipid Res., 11: 322 $(1970)$.

13. Lowry, O. H., Roschrough, N. J., Farr, A. L., and Randall, R. J.: Protein measurement with the Folin phenol reagent. J. Biol. Chem., 193: 265 (1951).

14. Lowry, O. H., Passonneau, J. V., Hasstberger, F. X., and Schule, D. W. Effect of ischemia on known substrates and cofactors of the glycolytic pathway in brain. J. Biol. Chem., 239: 18 (1964).

15. Makita, A., Suzuki, C., Yoshizawa, Z., and Konno, T.: Glycolipids isolated from the spleen of Gaucher's disease. Tohoku J. Exp. Med., 88: 277 $(1966)$.

16. Morrison, W. R., and Smith, L. M.: Preparation of fatty acid methyl esters and dimethylacetates from lipid with boron fuoride-methanol. J. Lipid. Res.. 5: $600(1964)$.

17. Öckerman, P. A. Identity of $\beta$-glucosidase, $\beta$-xylosidase and one of the $\beta$ galactosidase activities in human fiver when assayed with 4 -methylumbelliferyl- $\beta$-D)-glycosides studies in case of Gaucher's disease. Biochim. Biophys. Acta, 165: 59(1968).

18. Öckerman, P. A., and Kohlin, P.: Tissue acid hydrolase activities in Gaucher's disease. Scand. J. Clin. Lab. Invest., 22: 62 (1968).

19. Patrick, A. D.: A deficiency of glucocerebrosidase in Gaucher's disease. Biochem. J., 97: 17c (1965).

20. Robinson, D., Price, R. G., and Dance, N.: Separation and properties of $\beta$ galactosidase, $\beta$-glucosidase, $\beta$-glucuronidase and $N$-acetyl- $\beta$-glucosaminidase from rat kidney. Biochem. J., 102: 525 (1967)

21. Schncider, E. L., Ellis, W. G., Brady, R. O., McCulloch, J. R., and Epstein, C. J.: Infantile (type 11) Gaucher's disease: In utero diagnosis and fetal pathology. J. Pediat., 81: 1134 (1972)

22. Suomi, W. D., and Agranoff, B. W.: Lipids of the spleen in Gaucher's disease. J. Lipid Res., 6: 211 (1965).

23. We are grateful to Dr. H. Maesaka, Kanagawa Children's Medical Center. Kanagawa, and Dr. J. Sugiura, Department of Pediatrics, Nagoya University School of Medicine, Nagoya, who made the diagnosis of the patients as Gaucher's disease and referred them to us.

24. This work was supported in part by grants from the Ministry of Education in Japan for rescarch on inbern errors of metabolism, 1974-1975.

25. Requests for reprints should be addressed to: T. Kitagawa, M.D., Department of Pediatrics, Nihon University School of Medicine, 1-8 Kanda-Surugadai, Chiyoda-ku, Tokyo (Japan).

26. Received for publication September 9, 1975.

27. Accepted for publication October 14, 1976.

\title{
Trace Elements (Zinc, Cobalt, Selenium, Rubidium, Bromine, Gold) in Human Placenta and Newborn Liver at Birth
}

\author{
D. ALEXIOU, ${ }^{(\mathrm{H})}$ A. P. GRIMANIS, M. GRIMANI, G. PAPAEVANGELOU, E. KOUMANTAKIS, \\ AND C. PAPADATOS
}

Second Pediatric Clinic of the Universtiy of Athens: Demokritos Nuclear Research Center Chemistry Division, Athens, Grecere

Summary

Concentrations of zinc, cobalt, selenium, rubidium, bromium, and gold have been determined by neutron activation analysis in 18 placental and 6 liver tissue samples at birth. Their respective mean concentrations \pm standard deviations (parts per million) were $58 \pm 10,0.060 \pm 0.036,1.90 \pm 0.41,14.0 \pm 3.5,26.9 \pm$
14.3 , and $0.31 \pm 0.14$ in placenta, and $651 \pm 257,0.156 \pm$ $0.077,4.52 \pm 1.96,9.2 \pm 3.7,11.2 \pm 4.1$, and $0.12 \pm 0.06$ in liver tissue. Thus, we observed that the mean concentrations of essential trace elements (zinc, cobalt, and selenium) were significantly higher in liver than in placenta, whereas the nonessential trace elements (rubidium, bromium, and gold) were found in significantly higher concentrations in placenta than in liver tissue. 


\section{Speculation}

The observed difference in the distribution pattern of the studied trace elements in placenta and liver tissues should be extended to other essential and nonessential trace elements. It would also be interesting to study the distribution pattern of trace elements in various pathologic conditions of the fetus.

The concentration of trace elements in the human liver has been studied more extensively than in any other viscera. The levels of copper, chromium, zinc, manganese, cobalt, and iron in the liver in childhood have been reported by many authors $(3,8$, $11,12,13,14,17)$. It was shown that copper and manganese accumulate in the mitochondria and zinc in the cytoplasm of the liver cells, mainly as metalloenzymes $(2,6,15)$. Data referring to the concentrations of trace elements in the human placenta have been reported only for zinc, iron, copper, lead, and cadmium $(1,5,10,17)$. In the present investigation the concentrations of zinc $(\mathrm{Zn})$, cobalt $(\mathrm{Co})$, selenium $(\mathrm{Se})$, rubidium $(\mathrm{Rb})$, bromium $(\mathrm{Br})$, and gold $(\mathrm{Au})$ in the tissues of human placenta and liver at birth have been studied.

\section{MATERIALS AND METHODS}

Trace elements were determined in the tissues of 18 placentas taken at the time of birth, in the Alexandra Maternity Hospital. The placentas were selected randomly from women with normal pregnancies. Liver samples were also taken, within $24 \mathrm{hr}$ after birth, from six other newborns who died soon after birth. The causes of death were hypoxia or intracranial hemorrhage caused by birth injury.

Placenta samples $(7 \times 7 \mathrm{~cm})$ were cut from the center of the embryonic surface with a clean plastic knife. Then the samples were pressed strongly in order to squeeze out the remaining blood. The samples were placed in clean plastic bags and stored at $-20^{\circ}$. The same procedure was followed for the liver samples.

The tissue samples were analyzed at the Demokritos Nuclear Research Center, Athens, by the neutron activation analysis method (4). Two grams of tissue were placed into preweighed bottles and dried at $100^{\circ}$ for $20 \mathrm{hr}$. The dried samples were placed in quartz tubes. The concentrations (in micrograms per $\mathrm{ml}$ ) of elements in the standard solutions were as follows: $\mathrm{Zn}$,
$50 ; \mathrm{Br}, 5 ; \mathrm{Co}, 5 ; \mathrm{Rb}, 2 ; \mathrm{Se}, 0.09 ; \mathrm{Au}, 0.9$. The tubes were heat sealed and irradiated for $20 \mathrm{hr}$ in the swimming pool reactor, using the rotation system (thermal neutron flux, $2.2 \times 10^{1.3}$ neutrons $/ \mathrm{cm}^{2} / \mathrm{sec}$ ).

After irradiation quartz tubes containing the samples and standards were crushed in liquid nitrogen and the contents of tubes were transferred into clean tubes. Irradiated samples and standards were counted for $1 \mathrm{hr}$ in the germanium-lithium detector of a 4000 -channel analyzer. In samples and standards the areas under the photopeak corresponding to $\gamma$-rays of ${ }^{198} \mathrm{Au}$ at $411 \mathrm{keV}$, of ${ }^{{ }^{2} 2} \mathrm{Br}$ at $776 \mathrm{keV}$, of ${ }^{\mathrm{xt}} \mathrm{Rb}$ at $1077 \mathrm{keV}$, of ${ }^{65} \mathrm{Zn}$ at $1115 \mathrm{keV}$, of ${ }^{75} \mathrm{Se}$ at $264 \mathrm{keV}$, and of ${ }^{6 i} \mathrm{Co}$ at $1173 \mathrm{keV}$ and/or $1.332 \mathrm{keV}$ were compared. The data were processed by a CDC 3300 computer.

\section{RESULTS}

The individual as well as the mean values and standard deviations (parts per million in dry weight and micrograms per $100 \mathrm{~g}$ fresh tissue) of the studied trace elements in placenta and liver tissues are shown in Tables 1 and 2 .

Eighteen placentas were from newborns with mean gestational age of $39.3 \pm 4$ weeks and mean birth weight of $3,373 \pm 898 \mathrm{~g}$. Mean gestational age and mean birth weight of the six dead newborns from whom liver tissue was taken were $39.5 \pm 2.4$ weeks and $3,480 \pm 649 \mathrm{~g}$, respectively. The differences between the two groups were not statistically significant $(p>0.05)$.

Table 1 and 2 show that concentration of the studied trace elements do not vary substantially with gestational age. Furthermore, no significant correlation $(p>0.05)$ was found between gestational age and the concentration of each one of the studied trace elements in placenta as well as in liver tissue.

Further analysis of our results separately for each studied trace element is as follow's.

\section{ZINC}

The mean values of $\mathrm{Zn}$ concentrations in placenta and liver tissues were $58.1 \pm 10.1$ and $651 \pm 257 \mathrm{ppm}$, respectively. Thus, the concentration of $\mathrm{Zn}$ in liver tissue was 11 -fold higher than that in placenta. The difference was statistically very significant $(t=10.23 ; P<0.001)$.

Table 1. Individual (parts per million of dry matter) and mean values $\pm S D$ of trace element concentrations in placenta tissue

\begin{tabular}{|c|c|c|c|c|c|c|c|}
\hline No. & $\begin{array}{l}\text { Gestational age } \\
\text { (wecks) }\end{array}$ & $\mathrm{Zn}$ & $\mathrm{Co}$ & Se & $\mathrm{Br}$ & $\mathrm{Rb}$ & $\mathrm{Au}$ \\
\hline 1 & 29 & 60.8 & 0.050 & 1.68 & 8.3 & 12.0 & 0.27 \\
\hline 2 & 30 & 53.5 & 0.070 & 1.24 & 31.7 & 17.5 & 0.17 \\
\hline 3 & 38 & 77.8 & 0.130 & 2.67 & 52.5 & 12.7 & 0.49 \\
\hline 4 & 38 & 51.0 & 0.054 & 1.73 & 41.2 & 19.0 & 0.24 \\
\hline 5 & 39 & 66.3 & 0.040 & 1.86 & 13.7 & 11.1 & 0.50 \\
\hline 6 & 39 & 46.5 & 0.090 & 1.25 & 12.6 & 13.3 & 0.26 \\
\hline 7 & 40 & 61.0 & 0.020 & 2.38 & 32.5 & 19.6 & 0.22 \\
\hline 8 & 40 & 54.0 & 0.025 & 1.72 & 24.8 & 12.7 & 0.24 \\
\hline 9 & 40 & 60.7 & 0.140 & 2.37 & 13.6 & 15.8 & 0.21 \\
\hline 10 & 40 & 58.5 & 0.050 & 1.62 & 10.9 & 7.7 & 0.41 \\
\hline 11 & 40 & 55.1 & 0.036 & 1 & 52.7 & 7.8 & 0.35 \\
\hline 12 & 41 & 57.3 & 0.110 & 2.31 & 27.5 & 18.1 & 0.56 \\
\hline 13 & 41 & 77.7 & 0.040 & 2.13 & 22.3 & 12.0 & 0.12 \\
\hline 14 & 42 & 47.6 & 0.037 & 1.66 & 26.3 & 17.7 & 0.14 \\
\hline 15 & 42 & 48.5 & 0.072 & 2.13 & 47.0 & 14.8 & 0.48 \\
\hline 16 & 43 & 41.1 & 0.030 & 1.64 & 17.2 & 14.2 & 0.34 \\
\hline 17 & 43 & 70.0 & 0.070 & 2.32 & 21.7 & 12.7 & 0.26 \\
\hline 18 & 44 & 58.9 & 0.020 & 1.65 & 1 & 13.9 & 1 \\
\hline Mean \pm SD (ppm dry matter) & & $58 \pm 10$ & $0.060 \pm 0.036$ & $1.90 \pm 0.41$ & $26.9 \pm 14.3$ & $14.0 \pm 3.5$ & $0.31 \pm 0.14$ \\
\hline $\begin{array}{l}\text { Mean } \pm \mathrm{SD}(\mu / 100 \mathrm{~g} \text { fresh } \\
\text { tissuc })\end{array}$ & & $994 \pm 239$ & $1.04 \pm 0.65$ & $33 \pm 7.10$ & $522 \pm 283$ & $250 \pm 69$ & $5.45 \pm 2.60$ \\
\hline
\end{tabular}

${ }^{1}$ Missing sample. 
Table 2. Individual (parts per million of dry matter) and mean values $\pm S I$ ) of trace eleme'nt concentrations in liver tissue

\begin{tabular}{|c|c|c|c|c|c|c|c|}
\hline No. & $\begin{array}{l}\text { Gestational } \\
\text { age (weeks) }\end{array}$ & Zn & Co & $\mathrm{Se}$ & $\mathrm{Br}$ & $\mathrm{Rb}$ & $\mathrm{Au}$ \\
\hline 1 & 37 & 798 & 0.30 & 4.79 & 12.4 & 9.2 & 0.13 \\
\hline 2 & 37 & 436 & 0.09 & 3.38 & 7.8 & 4.7 & 0.06 \\
\hline 3 & 38 & 784 & 0.15 & 2.53 & 8.7 & 13.5 & 0.21 \\
\hline 4 & 41 & 405 & 0.09 & 5.81 & 9.3 & 5.4 & 0.08 \\
\hline 5 & 42 & 1,032 & 0.17 & 7.6 .5 & 18.8 & 13.3 & 0.17 \\
\hline 6 & 42 & 452 & 0.14 & 2.93 & 10.0 & 8.9 & 0.07 \\
\hline $\begin{array}{l}\text { Mean } \pm \text { SD (ppm dry mat- } \\
\text { ter) }\end{array}$ & & $6.51 \pm 257$ & $0.156 \pm 0.077$ & $4.52 \pm 1.96$ & $11.2 \pm 4.1$ & $9.2 \pm 3.7$ & $0.12 \pm 0.06$ \\
\hline $\begin{array}{l}\text { Mean } \pm \text { SD }(\mu \mathrm{g} / 100 \mathrm{~g} \text { fresh } \\
\text { tissue })\end{array}$ & & $14,3.34 \pm 0,004$ & $3.44 \pm 1.41$ & $99 \pm 4(1.2$ & $240 \pm 89$ & $199 \pm 83$ & $2.5 \pm 1.33$ \\
\hline
\end{tabular}

\section{COBALT}

The mean concentration of $\mathrm{Co}$ in liver tissue $(0.156 \pm 0.077$ ppm) was 2-fold higher than that in placenta $(0.060 \pm 0.036$ ppm). The difference was found to be statistically highly significant $(t=4.19 ; P<0.001)$.

\section{SILLINIUM}

The mean values of Se concentration in placenta and liver tissues were $1.90 \pm 0.41$ and $4.52 \pm 1.96$ ppm, respectively. Thus, the Se concentration in liver tissuc was 2 -fold higher than that in placenta. The difference was statistically significant $(t=$ $3.14 ; P<0.01)$.

\section{BRONIUN}

The mean concentration of $\mathrm{Br}$ in placenta $(26.9 \pm 1+.3 \mathrm{ppm})$ was 2-fold higher than that in liver tissuc (11.2 $\pm 4.1 \mathrm{ppm})$. The difference wass statistically significant $(t=2.60 ; P<0 .(12)$.

\section{RUBIIDIUN}

The mean concentrations of $R b$ in placenta and liver tissues were $14.0 \pm 3.5$ and $9.2 \pm 3.7 \mathrm{ppm}$, respectively. The level of $\mathrm{Rb}$ was higher in placenta than in liver tissue. The difference was statistically significant $(t=2.92 ; P<0.01)$.

\section{GOLI)}

Gold mean concentration was found also to be significantly higher $(t=3.28 ; P<0.01)$ in placenta $(0.31 \pm 0.14 \mathrm{ppm})$ than in liver tissue $(0.12 \pm 0.06 \mathrm{ppm})$. Thus, the level of $\mathrm{Au}$ in placenta was 3 -fold higher than that in liver tissue.

\section{DISCUSSION}

Widdowson and Spray (17) found a mean Zn concentration in placenta tissue of approximately $1 \mathrm{mg} / \mathrm{l} 00 \mathrm{~g}$ fresh tissue, which is comparable to our values (994 $\mu \mathrm{g} / 100 \mathrm{~g}$ fresh tissue).

$\mathrm{Zn}$ and Co concentrations in the liver were reported by many authors $(13,16,17)$. In the present investigation the $\mathrm{Zn}$ and $\mathrm{Co}$ mean liver concentrations, $14.3 \mathrm{mg} / 100 \mathrm{~g}$ and $3.44 \mu \mathrm{g} / 100 \mathrm{~g}$ fresh tissue, respectively, were found to be lower than those reported by Widdow'son et al. (16).

The distribution of trace elements in the human body has been considered as a method of determining whether an element is essential or nonessential $(7,9)$. We found that the amounts of essential trace elements as $\mathrm{Zn}, \mathrm{Co}$, and Se were significantly higher in liver than in placenta. On the other hand, the nonessential trace elements as $\mathrm{Br}, \mathrm{Rb}$, and $\mathrm{Au}$ have been found in higher concentrations in placenta than in liver tissue. Thus, although the studied sample is not large enough to draw final conclusions, we believe that our observation on the distribution pattern of trace elements in placenta and liver tissues is another example of the difference in distribution of essential and nonessential elements.

\section{CONCLUSION}

The concentrations of trace elements $(\mathrm{Zn}, \mathrm{Co}, \mathrm{Se}, \mathrm{Br}, \mathrm{Rb}$, and $A u$ ) in the placenta and liver tissues were determined by neutron activation analysis. Essental trace elements such as Zn, Co, and Se were found in significantly higher concentrations in liver than in placenta, whereas levels of nonessentials such as $\mathrm{Br}$. $\mathrm{Rb}$, and Au were higher in placenta than in liver tissue. Our observation on the distribution pattern of trace elements in placenta and liver tissues is another example of the difference in distribution of essential and nonessential elements.

\section{REFERIN( AS ANI) NOIIS}

1. Apte, S. V., Jengar, L., and Nagarajan, V.: Effect of antenatal iron supplementation on placental iron. Amer. J. Obstet. Gynecol. 1:0: 350 (1971)

2. Bartholomew, M. E... Tupper, R., and Wormall, $A$.: Incorporation of $\mathrm{Zn}_{\mathrm{n}}$ in the subcellular fractions of the liver and spontaneously occurring mammary tumors of mice after the injection of zine glycine containing ${ }^{6} \mathrm{Zn}$. Biochem. J.. 73 : $256(1959)$.

3. Brückman, G., and Zondek, S. G.: Iron, copper and manganese in human organs at various ages. Biechem. J., 33: 1845 (1939)

4. Comar, D. Clinical application of activation analysis. In: J. M1. A. Lenihan and S. L. X. Thomson: Advances in Activation Analysis, Vol. 1, pp. 16.3206 (Academic Press, New York, 1969)

5. Dawson, E. B., Croft, H. A., Clark, R. R., and MAGanity, W. J.: Study on nine cation levels in term placentas. II. Changes associated with toxemia of pregnancy and fetal prematurity. Amer. J. Obstet. Gynecol. 103: 1144 (1969)

6. Harrison, M. F.: Composition of the liver cell. Proc. Roy. Soc. B, 141:203 (1953).

7. Liebcher $k$ and Smith, H. Essential and nonessential trace elements: $A$ method of determining whether an element is essential or nonessential in human tissue. Arch. Environ. Health, 17: 881 (1968).

8. Mertz, W.: Chromium occurrence and function in biological systems. Physiol. Rev., 49: $163(1969)$.

9. Perry, H. M.. Tipton, 1. H. Schroeder, H. A., and Cook, M. J.: Varriability in the metal content of human organs. J. Lab. Clin. Med., 60: 245 (1962).

11). Poczekaj. J., Hejduk, J., and Chodera, A.: Behaviour of copper in tropher blast and in placenta at term. Gynaccolegia, 155: 155 (1963).

11. Ramage, H. Sheldem, J. H., and Sheldom, W.: A spectrographic investigation of the metallic content of the liver in childheod. Proc. Roy. Soc. B, 113: $308(1933)$.

12. Schrocder, H. A., Balassa, J. J., and Tiptom, I. H.: Abnormal trace metals in man: Chromium. J. Chron. Dis., 15: 941 (1962).

13. Schroeder, H. A. Nason, A. P., and Tipton, I. H.: Essential trace metals in man: Cobalt. J. (Chron. 1)is.. 20: 86,9 (1967).

14. Spray, C. M., and Widlowson, B. M.: The effect of growth and development on the composition of mammals. Brit. J. Nutr., 4: 332 (1950).

15. Thiers, R. F and Vallee, B. L.: Distribution of metals in subcellular functions of rat liver. J. Biol. Chem.. 226: 911 (1957).

16. Widdowson, E. M., Chan, H., Harrison, G. E., and Milner, R. D. G.: Accumulation of $\mathrm{Cu}, \mathrm{Zn}, \mathrm{Mn}, \mathrm{Cr}$ and $\mathrm{Co}$ in the human liver before birth. Biol. Neonate, 20: 360) (1972).

17. Widdowson, E. M., and Spray, C. M.: Chemical development in utero. Arch. Dis. Childhood. 26: 205 (1951).

18. Requests for reprints should be addressed to: D. Alexiou, M.D., Second Pediatric Clinic of the University of Athens. Aglaia Kyriakou Children's Hospital, Athens 6()8 (Greece)

19. Received for publication Junc 21, 1976

20. Accepted for publication October 14, 1976. 